DOI: https://doi.org/10.32839/2304-5809/2021-5-93-67

УДК 343.9

Шелепкова C.M. ${ }^{1}$

Харківський науково-дослідний експертно-криміналістичний центр Міністерства внутрішніх справ України

\title{
ЛІНГВІСТИЧНІ МЕТОДИ ДОСЛІДЖЕННЯ ГОЛОСУ \\ ТА МОВЛЕННЯ ЛЮДИНИ В УМОВАХ КОНТАКТНОГО БІЛІНГВІЗМУ НА МАТЕРІАЛІ СУДОВОЇ ЕКСПЕРТИЗИ ВІДЕО-, ЗВУКОЗАПИСУ
}

\begin{abstract}
Анотація. На сьогодні обставини багатьох категорій кримінальних і цивільних справ збільшують необхідність розширення розслідування злочинів засобами фріксації мовленневих повідомлень за допомогою високоякісної апаратури і проведення експертних ідентифрікаційних і діагностичних досліджень мовленнєвої інформації людей, які мають оперативний інтерес. Експертна практика показуе, що на експертизу найчастіше надходять (відео)фонограми, виконані в екстремальних умовах, що відображають стресовий стан людини, що безпосередньо позначається на роботі їі мовленневого апарату і, відповідно, на голосі та мовленні. Тому порівняння голосу та мовлення однієї і тієї ж людини в різних ситуаціях спілкування не завжди дозволяе ії підтвердити. Тим більше, що з метою відведення від себе підозри, підозрювана людина може навмисно змінити свій голос. Однак експерт з досвідом роботи встановлює достовірність джерела відомостей, а також фральсифікацію фронограми. Під час провадження судової експертизи відео-, звукозапису основним знаряддям, на відміну від інших експертиз, є слух експерта, який здатний узагальнити не тільки комплексну звукову інформацію фонограми, а й розділити цю інформацію таким чином, що дозволяе експерту одночасно говорити про зміст сказаного, лінгвістичні особливості голосу та мовлення людини, емоційний стан в момент запису, а також про навколишне середовище, у якому здійснювався звукозапис. На експертизу надходить особлива форма речових доказів - фонограми чи відеофонограми, що створені за допомогою технічних засобів і відображають в акустичній (звуковий) формі інформацію про злочинні дії. Зважаючи на викладене, постала нагальна потреба у розгляді лінгвістичних методів дослідження голосу та мовлення людини в умовах контактного білінгвізму на матеріалі судової експертизи відео-, звукозапису.
\end{abstract}

Ключові слова: судова експертиза відео-, звукозапису, лінгвістичний метод, голос і мовлення людини, білінгвізм, мова та мовлення, діалекти.

Shelepkova Svitlana Kharkiv Scientific Research Forensic Center of the Ministry tf Internal Affairs tf Ukraine

\section{LINGUISTIC METHODS OF RESEARCH OF HUMAN VOICE AND SPEECH IN CONDITIONS OF CONTACT BILINGUALISM ON THE MATERIAL OF FORENSIC VIDEO SOUND RECORDING}

Summary. Today, the circumstances of many categories of criminal and civil cases increase the need to expand the investigation of crimes by means of recording voice messages with high-quality equipment and conducting expert identification and diagnostic studies of speech information of people of operational interest and investigative actions. Expert practice shows that the examination most often receives (video) phonograms performed in extreme conditions, reflecting the stressful state of man, which directly affects the work of his speech apparatus and, accordingly, the voice and speech. Therefore, comparing the voice and speech of the same person in different communication situations does not always allow to confirm it. Moreover, in order to divert suspicion, the suspect may intentionally change his voice. However, an expert with experience establishes the reliability of the source of information, as well as the falsification of the phonogram. During the forensic examination of video and audio recording, the main tool, unlike other examinations, is the hearing of the expert, who is able to summarize not only the complex sound information of the phonogram, but also to divide this information so that the expert can talk about the content of linguistic features of human voice and speech, emotional state at the time of recording, as well as the environment in which the recording was made. The examination receives a very special form of physical evidence - phonograms or video phonograms, created with the help of technical means and reflect in acoustic (sound) form information about criminal acts. In view of the above, there is an urgent need to consider linguistic methods of studying the voice and speech of a person in terms of contact bilingualism on the material of forensic examination of video and sound recording. Bilingualism means a perfect command of the speaker in both languages, their parallel use. However, bilingualism is different because people learn another language differently. Therefore, when studying the voice and speech of bilinguals, it is necessary to take into account that human pronunciation skills are created by different perceptual bases. Everyone uses the perception of similarity with the units of their native language as a reliable support when studying a foreign language.

Keywords: forensic examination of video and sound recording, linguistic methods, voice and speech of a person, bilingualism, language and speech, dialects.

Постановка проблеми. Збільшення кри1 мінальних проваджень, пов'язаних із розкриттям і розслідуванням злочинів із засто- суванням методів тероризму, насильства, погроз, шантажу, викрадення людей, спричиняе і зростання експертних досліджень, які провадяться

\footnotetext{
${ }^{1}$ ORCID: http://orcid.org/0000-0003-3641-3475
} 
у Харківському експертно-криміналістичному центрі МВС України.

У зв'язку з цим виникла нагальна потреба розробки і впровадження в експертну практику нових методів дослідження судової експертизи відео-, звукозапису.

Відомо, що в своїх протиправних діях злочинці широко використовують різні засоби відео-, звукозапису, що обумовлено використанням досягнень у розвиткові технологій і засобів зв'язку, які обслуговують комерційну та економічну діяльність, перевезення, туризм тощо.

А тому в якості речових доказів про обставини, які підлягають встановленню у кримінальному провадженні, усе частіше використовують записи різного походження (фонограми та відеофонограми) i, зокрема, голос та мовлення людини, а також самі аудіовізуальні засоби.

Аналіз останніх досліджень i публікацій. Використання матеріалів відеозвукозапису в якості джерел доказової інформації викликає необхідність їх криміналістичного дослідження. Дослідженням відеозвукозаписів як речових доказів при розслідуванні кримінальних проваджень займається судова експертиза відео-, звукозапису, під час якої вирішуються різні питання, що мають відношення до голосу та мовлення людини, зафріксованих на відеозвукозаписах, а також сам носій, на якому зафіксований відеозвукозапис.

Однак основним завданням судової експертизи відео-, звукозапису є ідентифікація голосу та мовлення людини.

Процеси, що відбулися за останні роки, зробили актуальним проведення лінгвістичних методів дослідження судової експертизи відео-, звукозапису. Висвітлення ціеї тематики знаходимо у роботах таких дослідників, як: Р. І. Аванесов, В. М. Алпанов, О. І. Галяшина [4], В. В. Іванов, В. В. Потапов та Р. К. Потапова, Д. М. Ушаков.

Виділення невирішених раніше частин загальної проблеми. Проблема ідентифікації людини за голосом та мовленням $є$ актуальною у зв'язку із загостренням криміногенної обстановки, зростанням таких видів злочинів, як теледонний тероризм, вимагання, викрадення людей, шантаж і необхідністю підвищення ефрективності боротьби з ними з боку правоохоронних органів.

Розслідування і розкриття будь-яких злочинів вимагають встановлення осіб і предметів, пов'язаних зі злочином. Одним 3 найбільш поширених і едективних способів вирішення цього завдання $є$ ідентифрікація голосу та мовлення людини за наявними слідами.

При здійсненні таких безконтактних злочинів, як вимагання по телефону, анонімні телефонні повідомлення про вибух, фонограми/відеофонограми із записом розмов є єдиним речовим доказом у кримінальних провадженнях.

Метою статті $є$ аналіз лінгвістичних методів дослідження голосу та мовлення людини в умовах контактного білінгвізму на матеріалі судової експертизи відео-, звукозапису.

Виклад основного матеріалу. Варто зазначити, що мовна ситуащія всієї території України не $є$ однорідною. На півдні та сході України склалися сприятливі умови для розвитку та функщіонування масового білінгвізму. Переважна частина населення цих областей - хто на активному piвні, хто на пасивному - двомовна. Одна й та ж людина може постійно переходити протягом дня з російської на українську мову спілкування.

Білінгвізм або двомовність у лінгвістичному трактуванні визначається як практика почергового використання двох мов [3, с. 22]. При цьому вказується на головну рису цього явища - фрункціонування двох мов у спілкуванні одних i тих самих носіїв. Ця обставина особливо важлива, оскільки взаємодія систем реалізуеться лише y їх фрункщіонуванні. Для низки дослідників [7, с. 313-318] білінгвізм - це здатність тих чи інших груп населення спілкуватися двома мовами залежно від ситуації чи обставин.

У словниках лінгвістичних термінів білінгвізм розглядається як однаково досконале володіння двома мовами в різних умовах спілкування [1, с. 125].

Уважаючи білінгвізмом добре володіння і національною мовою, і мовою міжнаціонального спілкування, В. Русанівський наголошуе, що розвиток двомовності аж ніяк не є перепоною на шляху розвитку національних мов, навпаки, явище білінгвізму може бути одним 3 важливих джерел подальшого розвитку національних мов [6, с. 160].

Проте, незалежно від існуючих підходів до тлумачення терміна «білінгвізм», наявне різноманіття наукових поглядів щодо його сутності та походження можна розділити на дві групи.

Перша - трактує білінгвізм як однаково вільне володіння двома мовами, друга - допускає значні відмінності в знанні двох мов та наявність у білінгва різних ступенів (від низького до високого) володіння нерідною мовою, хоча й передбачає користування набутою мовою в ситуації спілкування 3 носієм мови.

Ці дві групи поглядів відображають вузьке й широке розуміння двомовності. Так, низка дослідників [2, с. 61] вважають, що термін «білінгвізм» можна використовувати лише в тому випадку, якщо володіння другою мовою наближається до володіння рідною.

Інші вчені [5, с. 11], навпаки, стверджують, що за умов білінгвізму ступінь володіння однією 3 мов може бути й досить низьким.

Зважаючи на географічне розміщення Харківської області, її близькість з Белгородською областю, а також наявність різних контактів населення, нагальним є створення мовленнєвого портрета людини 3 метою криміналістичного розпізнавання особистості людини.

Однією 3 активно досліджуваних проблем у теорії мовленнєвих контактів є на сьогодні вивчення результатів взаємодії близькоспоріднених мов, оскільки на теренах України набуло широкого розповсюдження білінгвальне мовлення, що являе собою активне використання російських компонентів в українському мовленні.

Деякі дослідники такий різновид мовлення вважають суржиком і визначають його як негативний результат взаємодії російської та української мов, що засвідчує низький культурно-освітній рівень населення.

Однак, на нашу думку, суржик становить більш широке явище, складовими якого разом з білінгвізмом $є$ просторічні елементи, діалектизми, жаргонізми тощо.

При проведенні судової експертизи відео-, звукозапису часто виникає питання визначення 
соціально-фрізичних характеристик людей, усне мовлення яких зафіксоване на досліджуваній фонограмі, встановлення можливих географрічних районів їх проживання тощо.

Особливо актуальним дане питання $є$ тоді, коли коло підозрюваних є великим, або коли в наявності є лише запис досліджуваного голосу та мовлення на носієві, а підозрювана особа відсутня (наприклад, при анонілних телеббонних повідолленнях тощо).

Тоді, як правило, виникає потреба діагностичного дослідження усного голосу та мовлення людини з метою встановлення іï індивідуальних ознак.

При діагностичному дослідженні (відео)фронограм із записом голосу та мовлення людини однією із найбільш інформативних ознак, яка характеризує усне мовлення людини, як показує експертна практика, є діалекти, які $є$ повними мовними системами, що надають своїм носіям всі засоби і рівні мовленнєвого спілкування.

Комплексний підхід до вивчення характеристик діалектних груп української мови у криміналістиці досі не розглядався, хоча у спеціальній літературі робилися спроби визначення ознак, характерних для певних діалектних груп.

Вивчення місцевих, територіальних та соціальних діалектів української мови, фонетичних, морфологічних та синтаксичних особливостей основних діалектних груп української мови дасть можливість вирішити широкий спектр практичних завдань, які стоять перед правоохоронними органами, що е особливо важливим на стадії дізнання.

На відміну від літературної, діалектна мова характеризується відсутністю писаних для неї правил, мінливістю своєї будови в різних частинах етнічних територій, переважно усною фрормою вияву і відносно обмеженою сферою вживання. Завдяки підвищенню рівня освіти люди все більше стали говорити відповідно до норм літературної мови, але розмовна мова багатьох з них має ознаки того діалекту, який характерний для місця їх походження. Більше того, людина, яка розмовляе літературною мовою, в певному стресовому або емоційному стані виявляе ознаки того діалекту, який характерний для місцевості, де вона народилася або довго проживала.

Місиеві, територіальні діалекти мають свої особливості, свої специфрічні ознаки на різних мовних рівнях - у фонетиці, граматиці, словотворенні, лексиці.

Серед основних родових ознак, характерних для російської мови жителів України, виділимо такі:

- при вилові голосних звуків:

- більш тривале звучання голосних у сильній позиції, що іноді призводить до дифтонгового звучання йотованих голосних;

- подовження голосних у слабких позиціях, співпадіння першого і другого ступеня редукції;

- вимова більш відкритого голосного на місці звуку [ы];

- при вилові приголосних звуків:

- вимова на місці проривного [г] фррикативного [h];

- губно-губна, а не губно-зубна вимова приголосного [в];

- повне або часткове ствердіння сонорних перед голосними переднього ряду;
- недостатне пом'якшення губних приголосних [б], [п], [в], [м], [ф] i [p] перед голосними переднього ряду в середині слова або заміна їх твердими в кінці слова;

- йотація після губних приголосних;

- відсутність асиміляції за глухістю наприкінці слів і перед глухим приголосним;

- наявність м'якого варіанту африкати [ц];

- напівм'який або твердий шиплячий [ч];

- вимова шиплячого «щ» як [шч];

- поява африкат [дж], [дз] на місці «д»;

- відсутність пом'якшення сонорного [м] у закінченнях іменника, прикметника, займенника, числівника і діеприкметника в орудному відмінку множини;

- на рівні лексики:

- наявність українських нелексиколізованих запозичень;

- на лорбологічнолу рівні:

- змішування категорії роду іменника;

- вживання в російській мові прийменників, нормативних для української;

- вживання займенника «ихний»;

- на синтаксичнолу рівні:

- порушення норм керування в прийменникових конструкціях;

- велика кількість приеднань у складному реченні за допомогою сполучника «что» замість «который».

Соціальна диференціація мови здавна супроводжує і їі територіальну диференціацію, оскільки між носіями місцевих діалектів існують відмінності в мові, які зумовлені різним рівнем їх освіти, загальної культури, родом занять тощо.

Експертна практика показуе, що при визначенні географрічного району формування усної мови, місць тривалого проживання і рідної мови дикторів найбільш важливу роль відіграють фонетичні і лексичні особливості мови, а при визначенні соціальних характеристик (професії тощо), перш за все, слід враховувати лексичний склад i фрразеологічні особливості мови. Також досліджено, що найбільш стійко традиційні діалектні особливості проявляються у людей старшого віку, у осіб, які безвиїзно живуть у своїй місиевості, у жінок - більше, ніж у чоловіків.

Із застосуванням засобів звукозапису в практичну діяльність органів МВС при встановленні особи за (відео)фонограмою голосу та мовлення використовувався акцент як яскрава мовленнєва особливість людини.

У кожній мові при вимові звуків органи мовлення здійснюють звичні і необхідні рухи за системою рідної мови. Одна мовленнева поза змінюеться іншою, утворюючи звуки мови, якість яких повинна відповідати орфоепічним нормам цієї мови.

Тому засвоєння чужої артикуляційної бази пов'язане з труднощами, а невідповідності його системі рідної мови утворюють акцент, який $\epsilon$ яскравою діагностичною ознакою.

Під акцентом розуміеться своєрідна вимова: звуки нерідної мови мимоволі замінюються звуками рідної мови.

При взаємодії контактуючих мов система другої мови накладається на систему рідної, викликаючи позитивне і негативне перенесення знань, умінь і навичок рідної мови на іншу мову. 
Висновки і пропозиції. Науковою основою слухового методу повинно бути знання експертом механізму вимови звуків, системи вимови навичок, їх формування та закономірностей індивідуальності вимови.

$\mathrm{У}$ діях експерта значну роль відіграє його слуховий досвід, слухова пам'ять, від яких залежить виявлення не тільки фонетичних ознак усного мовлення, а й різноманітних акустичних явищ.

Тому вважаеться доведеним, що на основі слухового аналізу, з тим або іншим ступенем ймовірності, можна визначити район формування усного мовлення та можливі місця тривалого проживання людини, яка ідентифікуеться, наявність патології мовлення.

При цьому експерт порівняно легко адаптуеться до досить високого рівня перешкод і спотворень, які часто мають місце в досліджуваних фонограмах.
Пріоритетність лінгвістичного методу дослідження голосу та мовлення людини в умовах контактного білінгвізму на матеріалі судової експертизи відео-, звукозапису полягае в тому, що експерт при виділенні лінгвістичних ознак здатний сприймати найтонші нюанси звучання голосу та мовлення, оцінювати відмінності, що не піддаються в даний час інструментальним методам дослідження (відео)фонограм.

Аналіз із застосуванням методики судової експертизи відео-, звукозапису зі встановлення національної приналежності людини, регіону іï проживання та створення мовленневого портрета людини, в якому показано відповідність або невідповідність вимови людини системі норм нерідної мови, представляе велику цінність при отриманні розшукової інформації для оперативних служб, слідства і суду.

\section{Список літератури:}

1. Ахманова О.С. Словарь лингвистических терминов. Москва : КомКнига, 2005. 576 с.

2. Блумфиллд Л. Язык / Пер. с англ. Москва : Прогресс, 1968. 607 с.

3. Вайнрайх У. Языковые контакты. Состояние и проблемы исследования / Пер. с англ. языка и комментарий Ю.А. Жлуктенко. Киев : Вища школа, 1979. 263 с.

4. Галяшина Е.И. Основы судебного речеведения. Москва, 2003. 236 с.

5. Розенцвейг В.Ю. Языковые контакты. Л. : Наука, $1972.80 \mathrm{c.}$

6. Філософські питання мовознавства / Відп. ред. В.М. Русанівський. Київ : Наукова думка, 1972. 199 с.

7. Щерба Л.В. Языковая система и речевая деятельность. Москва, 2004. 432 с.

\section{References:}

1. Akhmanova O.S. (2005) Slovar' lingvisticheskikh terminov [Dictionary of linguistic terms]. Moscow: KomKniga, 576 p. (in Russian)

2. Blumfild L. (1968) Yazyk / Per. s angl. [Language: Per. from English]. Moscow: Progress, 607 p. (in Russian)

3. Vaynraykh U. (1979) Yazykovyye kontakty. Sostoyaniye i problemy issledovaniya [Language contacts. State and problems of research / Per. from English language and commentary by Yu. A. Zhluktenko]. Kyiv: Vishcha shkola, 263 p. (in Ukrainian)

4. Galyashina Ye.I. (2003) Osnovy sudebnogo rechevedeniya [The basics of judicial speech]. Moscow, $236 \mathrm{p}$. (in Russian)

5. Rozentsveyg V.Yu. (1972) Yazykovyye kontakty [Language contacts]. L.: Nauka, 80 p. (in Russian)

6. Rusanivs'kyy V.M. (vidp. red.) (1972) Filosofs'ki pytannya movoznavstva [Philosophical issues of linguistics]. Kyiv: Naukova dumka, 199 p. (in Ukrainian)

7. Shcherba L.V. (2004) Yazykovaya sistema i rechevaya deyatel'nost' [Language system and speech activity]. Moscow: Yeditorial URSS. M., 432 p. (in Russian) 